AGRARIS: Journal of Agribusiness and Rural Development Research

Vol. 7 No. 1 January-June 2021 Pages: $37-52$

Article history:

Submitted: July $21^{\text {st }}, 2020$

Accepted: November $12^{\text {th }}, 2020$
Natelda Rosaldiah Timisela1,*, Masyhuri Masyhuri², Dwidjono Hadi Darwanto ${ }^{2}$

1 Fakultas Pertanian, Universitas Pattimura, Ambon, Indonesia

${ }^{2}$ Fakultas Pertanian, Universitas Gadjah Mada, Yogyakarta, Indonesia

\title{
Development Strategy of Sago Local Food Agroindustry Using Analytical Hierarchy Process Method
}

\author{
DOI: https://doi.org/10.18196/agraris.v7i1.9378
}

\begin{abstract}
This study aims to formulate the development strategy for sago local food agroindustry in Maluku Province. The sample was taken deliberately (purposive sampling) because respondents realize the sago development in the province. The respondents, totaling 15 people, consisted of farmers, traders, and experts from several agencies, namely the Food Security Agency, the Department of Agriculture, the Department of Industry and Commerce, the Department of Cooperatives and Small and Medium Micro Enterprises, Universities, and NonGovernmental Organizations. Data analysis utilized the Analytic Hierarchy Process method. The priority analysis results of sago agroindustry development strategy revealed technology as a top priority in the agroindustry development for being associated with very low and limited assistance and access to processing technology. The sago local food agroindustry development focuses on linkages between factors, sub-factors, actors, objectives, and policy scenarios. The recommended policy scenarios are preserving local food, improving technology, arranging marketing strategies, improving production facilities and infrastructure, and improving institutional systems.
\end{abstract}

Keywords: Strategy, agroindustry, local food, sago, analytic hierarchy process.

\section{INTRODUCTION}

In Indonesia, the economic policy believed to be the key to national economic growth is the industrial sector. The industrial sector has contributed to the largest gross domestic product (GDP), influenced by government policies and strategies, a conducive market climate, and industry players' response. It contributed $20.07 \%$ to economic growth. The government spurs the industrial sector's performance, thereby continuing to drive the wheels of the Indonesian economy.

Indonesia's industrial development is inseparable from large and small industries. Small industries are frequently found in rural areas in the form of processing local raw materials into valuable finished products. Local sources of raw materials available in rural areas are highly prospective to be processed into essential foodstuffs substitute for rice. It is because local food can be processed into value-added and worth-selling food. To realize it, proper processing technology and marketing strategy must change the perspective that local 
food as inferior food will become ordinary and superior food (Ariani, Hermanto, Hardono, Sugiarto, \& Wahyudi, 2013).

Agroindustrial activities are an integral part of the agricultural sector development. The agroindustry effect can transform primary products into processed products and a low valueadded work culture into a modern industrial work culture creating high added value (Suryana, 2005).

Agroindustry refers to an industry utilizing agricultural products as its primary raw material. It can also be defined as an industry producing a product used as a means or input in agricultural business. It includes agricultural product processing industries, industries producing agricultural equipment and machinery, agricultural input industries (fertilizers, pesticides, herbicides and others) and service industries in the agricultural sector (Udayana, 2011).

Research on agroindustrial development strategies has been carried out, such as strategy planning formulation for agroindustry based on cassava to anticipate climate change (Kusnandar, Rahayu, Setyowati, \& Sutrisno, 2016), natural silk agrindustry (Tarigan, Fauzi, Sukardi, Suryani, \& Kaomini, 2010), a prospective strategy for the institutional development of Gayo coffee agroindustry, a review on the development strategies of agroindustrial institutions (Fadhil, Maarif, Bantacut, \& Hermawan, 2018; Fadhil, Syamsul, Bantacut, \& Hermawan, 2017), agroindustrial cluster development strategy (Putri et.al., 2015), agroindustrial development strategy based on integrated farming sytems in tidal areas (Massinai, Sudira, Mawardi, \& Darwanto, 2013), strategic management of agribusiness: determinants and trends (Chen, Yueh, \& Liang, 2016), the potentials of agroindustry for growth promotion and quality improvement in Indonesia (Fatah, 2007), agroindustry development policy: a strategy towards poverty alleviation (Yamin, Ali, MI, Fahmid, \& Asri, 2018), potential and development strategy of cocoa agroindustry (Rosmawaty, Wunawarsih, Bahari, \& Yusria, 2017), strategy for developing the capacity of sago managers in Central Maluku, Maluku Province (Tahitu, Saleh, Lubis, \& Susanto, 2016), strategy for developing a sago flour business in Tebing Tinggi Barat District, Meranti Islands Regency (Nurhayati, Sumarno, \& Indrawati, 2016), sago agroindustry development strategy, Indragiri Hilir Regency of Riau (Kurnia \& Al-Irsyadsyah, 2017), development strategy for leading food commodities in support of regional food security (case study in Batang Regency, Central Java Province) (Wijaya, 2017).

The agroindustrial development strategy requires government intervention, especially in overcoming limited capital, low quality of products, and limited technology. Increasing capital can be carried out by facilitating access to financial institutions, both bank and nonbank. Technology improvement assistance can be provided through both central and local governments. Increasing human resources, both increasing skills and awareness to make changes to improve product quality, can be performed through training and socialization through government assistance, both central and regional (Tarigan et al., 2010).

Rural communities generally operate sago agroindustry on a small scale, simple equipment and technology, and limited capital, causing low production, quality, and 
efficiency. Agroindustrial development possesses strategic value as it can provide employment, increase added-value and income, and improve the community economy. It is expected that sago agroindustry development can increase community and village income, added and selling values, open jobs, and improve community welfare. The agroindustrial development has linkages from upstream to downstream. Upstream actors supporting sago agroindustrial activities are farmers. They have raw materials and labors but limited technology, capital, and information (Kurnia \& Al-Irsyadsyah, 2017).

So far, the sago industry has grown quite well with the existence of a home industry developed by entrepreneurs in rural areas because it helps improve the living standard of the community. The sago home industry creates value-added products, stimulates rural economic growth, becomes the primary or secondary source of income, and creates jobs for the surrounding community (Timisela, Masyhuri, Darwanto, \& Hartono, 2014).

Other researchers have carried out various studies on agroindustrial development strategies. However, research on the sago agroindustry has not been widely conducted. Therefore, researchers are interested in researching the development strategy of the local sago agroindustry in Maluku Province. The research novelty comes from several aspects, such as the research location since Maluku Province has never conducted a study on the development strategy of the local sago agroindustry; the local food commodity in which sago serves as research icon; the research sample consisting of farmers, artisans, traders, consumers and policymakers; and analysis using process hierarchy analysis.

\section{RESEARCH METHOD}

The research was conducted in Central Maluku Regency, Maluku Province. Sampling was carried out deliberately (purposive sampling) because the respondents were aware of Maluku's sago development. The respondents consisting of 15 people comprised farmers, traders, business people and experts from several agencies, namely the Food Security Agency, the Department of Agriculture, the Department of Industry and Commerce, the Department of Cooperatives and Small and Medium Micro Enterprises, Universities, and NonGovernmental Organizations (NGOs).

The data collection method utilized questionnaires and structured interviews. The theory of measurement by making pairwise comparisons and relying on expert judgment to obtain a priority scale is part of the Analytic Hierarchy Process (AHP) (Saaty, 2008). Data collection using the AHP method is more efficient as it is based on the experiences and judgments of actors/decision-makers/experts in the field. AHP was designed to capture people's perceptions on a preference scale (tendency) to various alternatives or choices (Raharja, Rivani, \& Afifianti, 2018). The data were measured using a scale of 1 (equally important), 3 (slightly more important), 5 (clearly more important), 7 (very clearly important), 9 (absolutely more important), and 2, 4, 6, 8 (doubtful between two adjacent values or compromise values) depicting the comparison of the element importance. Drawing conclusions was carried out by accumulating global values or weights, the priority values of each element. AHP helped solve complex problems by compiling a hierarchy of criteria, 
assessed subjectively by interested parties, and then drew various considerations to develop weights or priorities (conclusions).

Data processing was performed using the AHP method. A pairwise comparison was carried out by analyzing the hierarchical relationship between the focus, factors, objectives, actors, and agroindustry development policies from various criteria and alternatives. Each element and other elements were made comparisons at the hierarchical level in pairs, then the importance of each element concerning qualitative opinions was obtained (Figure 1).

After that, the qualitative opinion was quantified using a rating scale and the opinion value was obtained in numbers (quantitative). AHP analysis utilizes human perception to determine comprehensive decisions. Each pairwise comparison was evaluated on Saaty's scale 1-9. AHP data analysis employed the Expert Choice application version 11.

The pairwise comparison matrix started at the top of the hierarchy for focus $G$, which was the basis for making pairwise comparisons between the related variables below it. The first pairwise comparison was carried out on the second level variables (F1, F2, F3, ..., Fn) to the focus at the top of the hierarchy, and so on until the last level hierarchy.

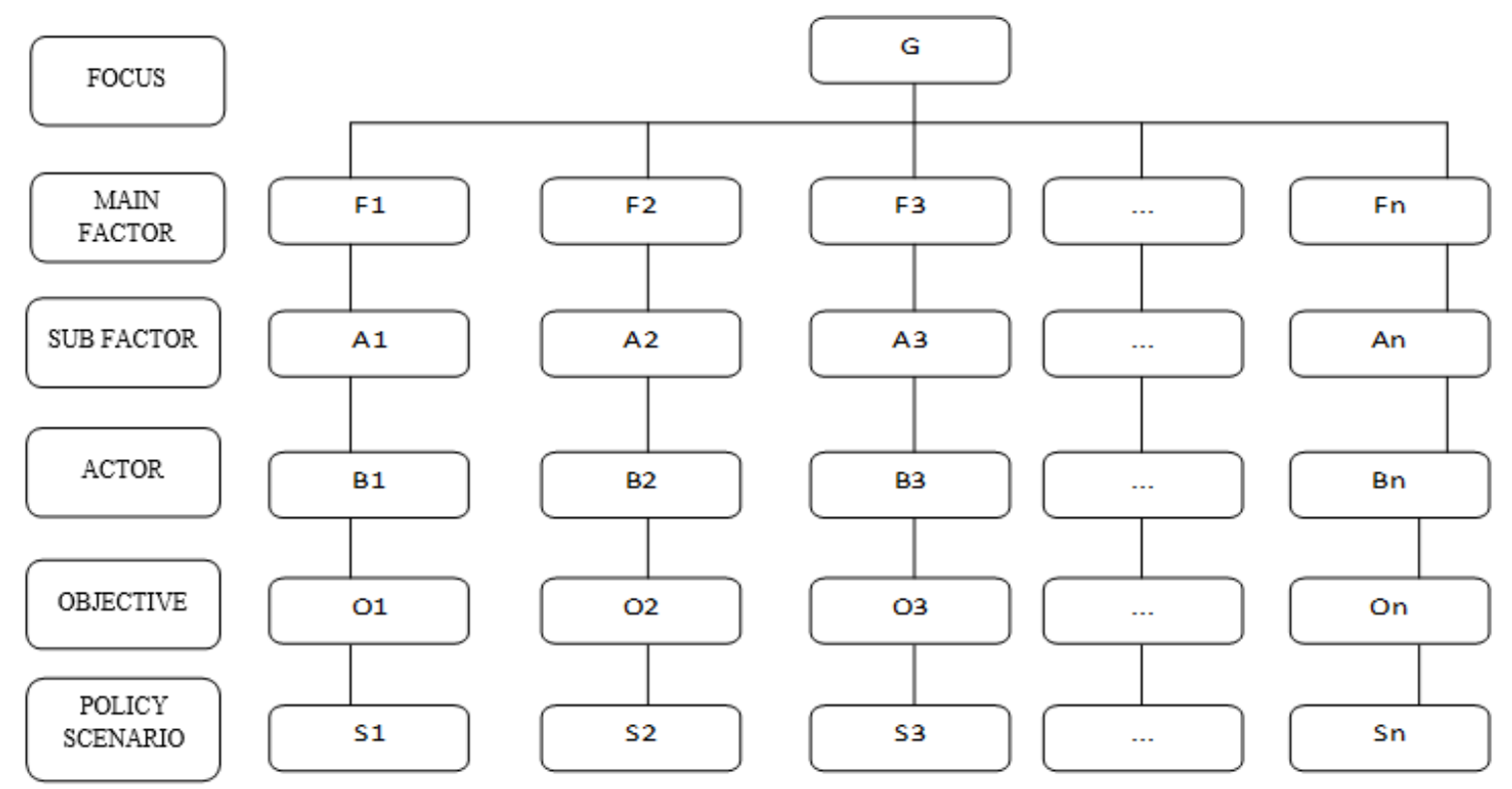

Source : (Didu, 2000).

FIGURE 1. A FRAMEWORK OF DECISION MAKING HIERARCHY PROCESS

\section{RESULT AND DISCUSSIONS}

\section{Contributing Factors of Sago Agroindustry Development}

Agroindustry players require technological aspects to improve the quality and creativity of their business. The analysis results of factors making up sago agroindustry development are presented in Figure 2. The technology related to packaging is still classified as weak so that the product packaging must be ordered from outside the region by sago agro-industry players. The function of packaging is not only protective but also a medium of interaction for communication between consumers and producers (Kumar, Agarwal, Singh, \& Singhal, 2017). Therefore, packaging is a main priority, because packaging must be good and of good 
quality so that a positive response from consumers to buy products is created because the purpose of packaging is to create and increase sales (Chalids, Najib, \& Suparno, 2019).

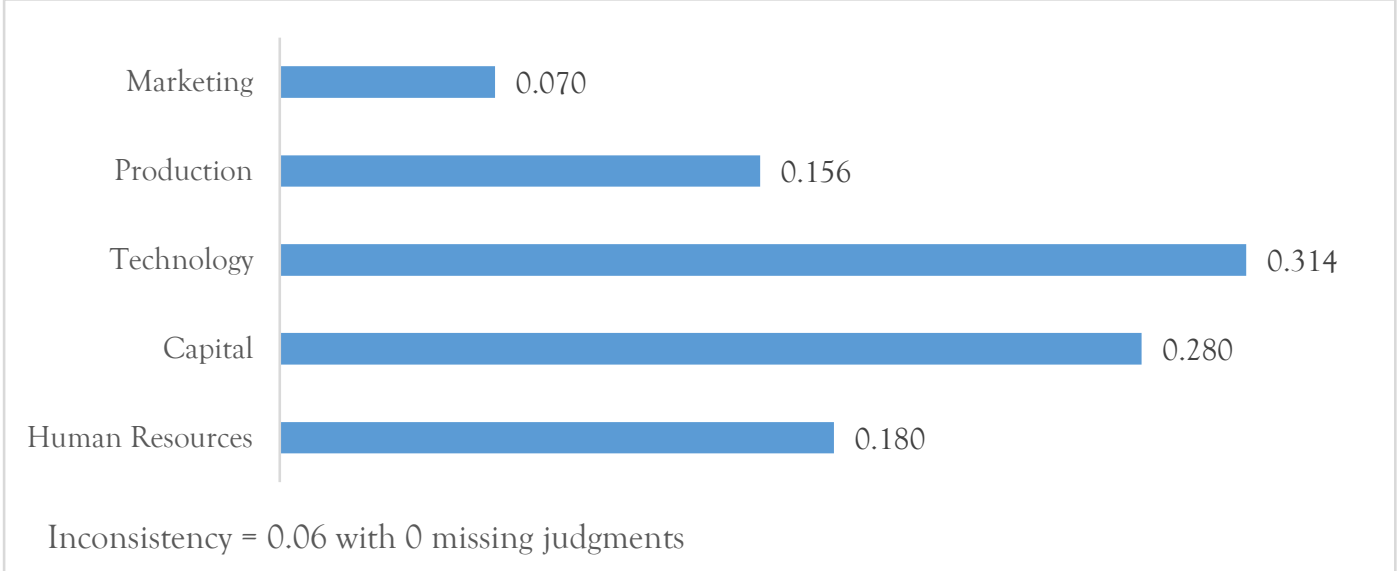

FIGURE 2. CONTRIBUTING FACTORS OF SAGO AGROINDUSTRY DEVELOPMENT

Sub-Factors of Human Resources (HR), Capital, Technology, Agroindustry Production and Marketing for Sago Agroindustry Development

The results of the HR sub-factor analysis for sago agroindustry development are depicted in Figure 3. The HR aspects of agroindustry players consist of three alternatives, technical skills training, business management training, as well as motivation and business skills. Technical skills training is a top priority as it is related to the traditional agroindustrial production process. Sago agroindustrial entrepreneurs have good technical skills to create sago products. Most traditional sago products are more dominant in the market. It is a priority because entrepreneurs do not want to lose Maluku sago's characteristics, famous from the past. Many changes in sago production techniques toward modern ones have been carried out due to training and assistance from related agencies to improve technical business skills. Management training takes second place due to the weak management aspect among agroindustry players, especially for business bookkeeping, financial management, and production system regulation. This activity must be addressed in a better direction. Agroindustry actors' motivation and business skills are very high, wishing to adopt quality business skills and motivation for sustainable agroindustrial development. It is in line with Herdhiansyah \& Asriani (2018), stating that agroindustry is an effort to increase added-value in cocoa production because it will increase farmer independence through coaching, counseling, and developing partnerships.

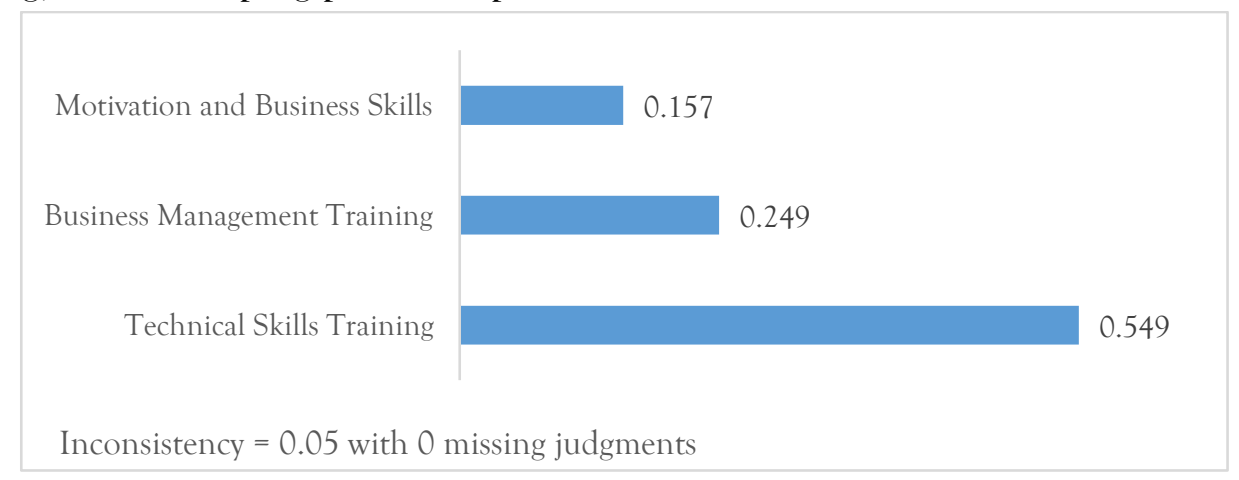

FIGURE 3. AGROINDUSTRY HR SUB-FACTORS FOR SAGO AGROINDUSTRY DEVELOPMENT 
Figure 4 displays the sub-factor analysis of capital for sago agroindustry development. The agroindustrial business requires capital and skills. Entrepreneurs frequently face difficulty obtaining venture capital. They expect access to obtaining capital easier and faster with low interest. Agroindustry entrepreneurs urgently require government-owned capital institutions and other capital institutions for sustainable business development. The capital aspect consists of two alternatives, providing capital assistance and opportunities for access to capital. Capital assistance is the top priority because business development highly requires it. Entrepreneurs run businesses with their capital due to the difficulty in obtaining loan capital because of a convoluted process, many requirements, high loan interest, making a business proposal feasible and profitable, and disbursing funds long. Moreover, they expect capital assistance in business equipment and product processing machines. However, the process sometimes takes a long time because entrepreneurs have to form business groups to receive this assistance.

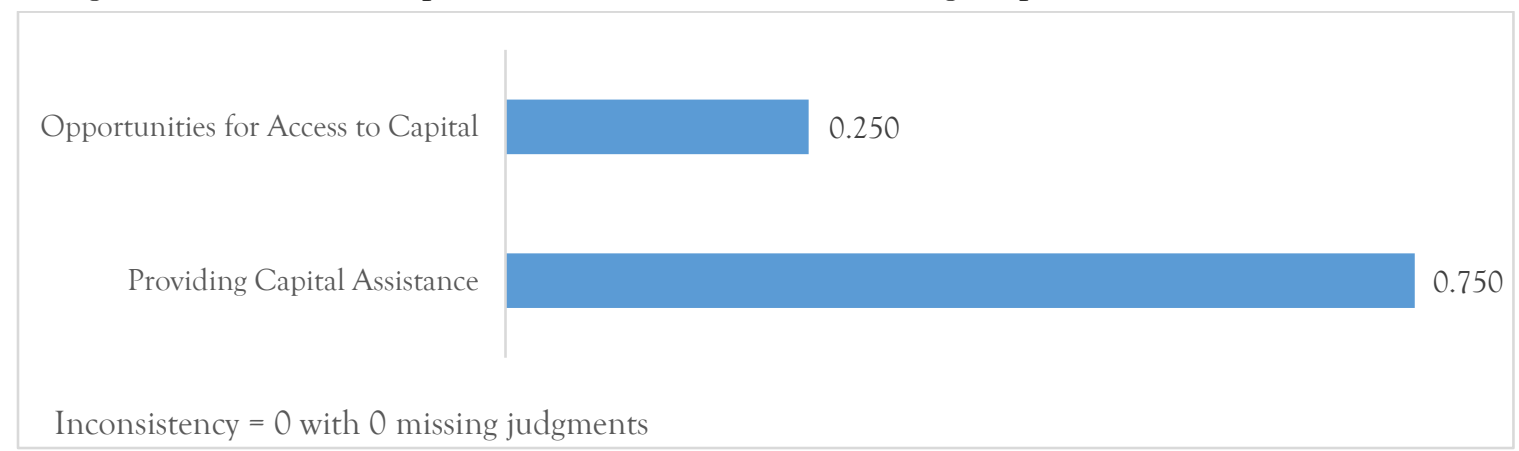

FIGURE 4. CAPITAL SUB-FACTOR FOR SAGO AGROINDUSTRY DEVELOPMENT

Opportunities for easy, fast and precise access to capital are hard to obtain. There are many capital institutions in the region, such as banks, cooperatives, private financial institutions and others. However, the opportunity for entrepreneurs to access capital has encountered obstacles. In regards to this, entrepreneurs are quite familiar with banks as capital institutions with collateral requirements. Most entrepreneurs have access to other financings, such as investment. If the investment is opened for the agroindustrial business, they must consider several policies, timeframes, taxes, regulations, treatment, land rights, infrastructure, and business climate.

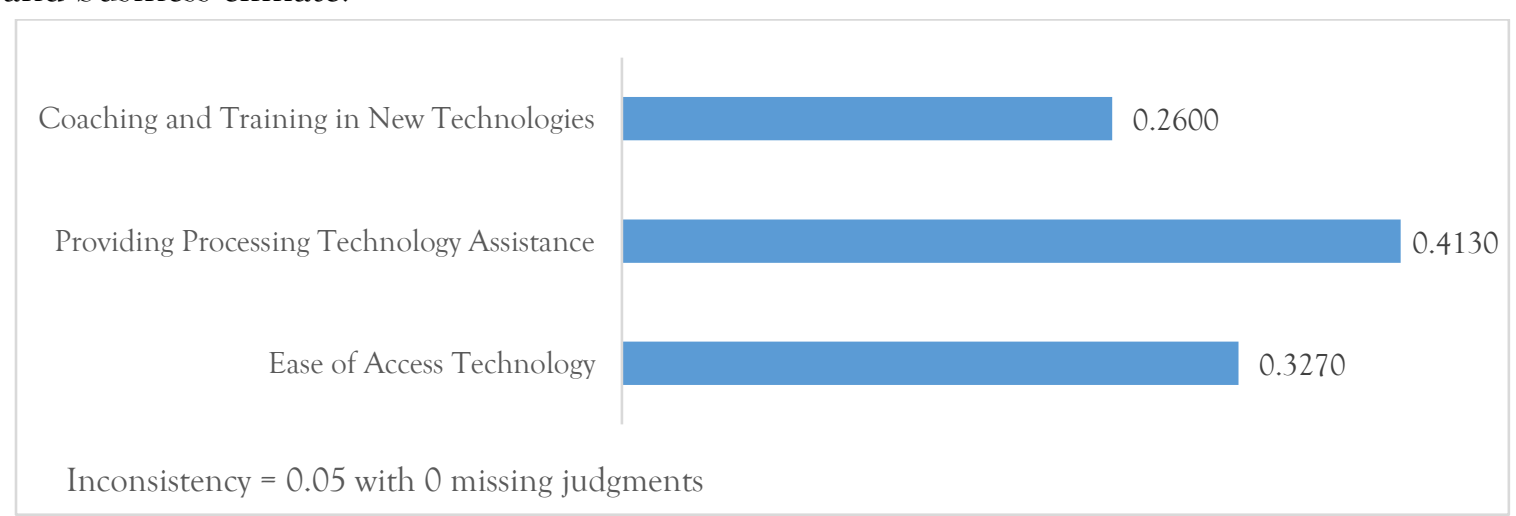

\section{FIGURE 5. SUB-FACTOR TECHNOLOGY FOR SAGO AGROINDUSTRY DEVELOPMENT}

The results of the sub-factor analysis of technology for sago agroindustry development are shown at Figure 5. The technology aspect consists of three alternatives, easy access to 
technology, providing processing technology assistance, as well as coaching and training in new technology. Technology in the agroindustry is essential because entrepreneurs can design, modify and diversify sago local food into value-added, marketable and competitive products. Processing technology assistance is a top priority to support production activities. Cheap and fast technological assistance is required to encourage sago agroindustry development. It is supported by the research of (Apulu \& Latham, 2011) that the adoption of technology is vital to compete and improve business services.

The results of the sub-factor analysis of production for sago agroindustry development are shown at Figure 6. The production aspect consists of three alternatives, modification and production effectiveness, easy access to raw materials, and improving the quality of local food products. Easy of access to raw materials is a top priority to allow entrepreneurs to get raw materials more easily. Sufficient raw materials are available to answer the needs of the agroindustry to produce more products.

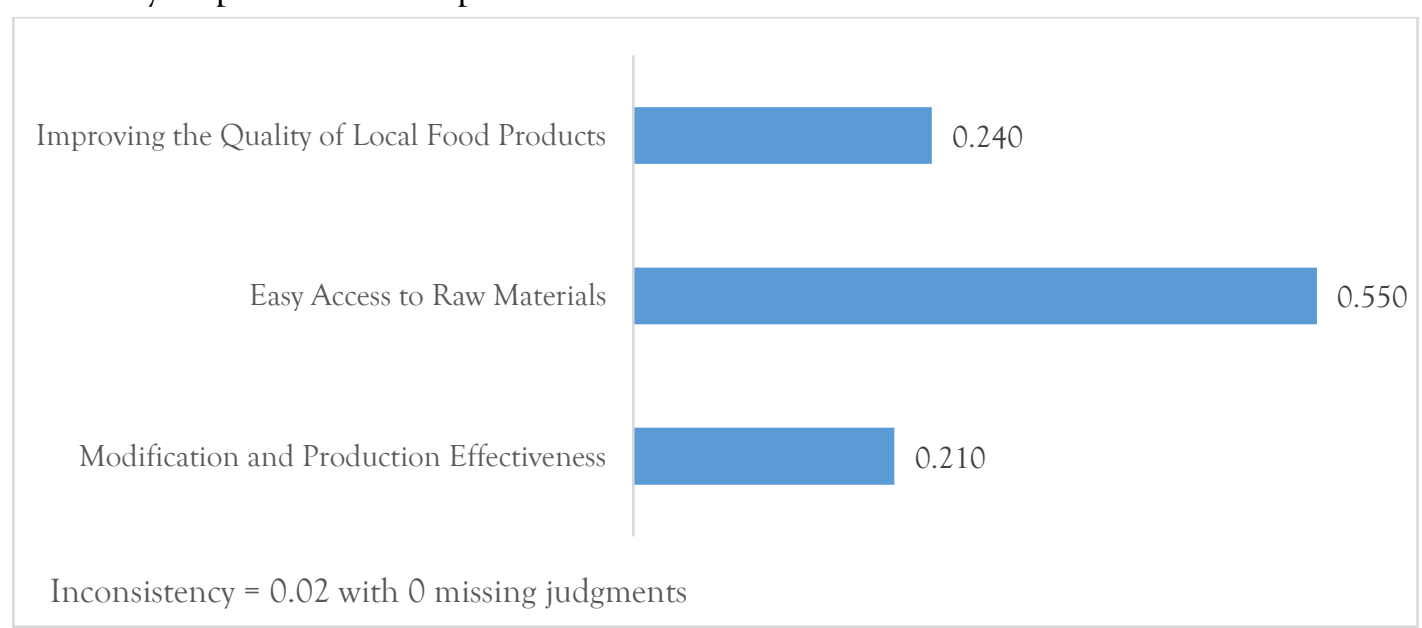

\section{FIGURE 6. PRODUCTION SUB-FACTORS FOR SAGO AGROINDUSTRY DEVELOPMENT}

Due to certain limited products, modification and production effectiveness must be increased. Sago agroindustrial products are divided into two parts, modern and traditional. However, more traditional products are produced than modern products, thereby requiring an increase in the modification of traditional products into modern ones. Creating modifications or innovations or new product variations using materials easier and cheaper aims to attract consumer interest and reduce production costs (Gultom \& Sulistyowati, 2018). Modern products produced by entrepreneurs must be more effective. Quality products are in demand by consumers; therefore, entrepreneurs should create quality products to increase consumer purchasing power. It is in line with the research of Andriani, Astari, Budhiarti, \& Zachary (2017) that improving innovative products according to the times and maintaining product quality can compete with other products.

Figure 7 presents the marketing sub-factor analysis results for sago agroindustry development. The marketing aspect consists of three alternatives, market information nets, promotion, and opening up market opportunities. Promotion is a means of introducing products to consumers. It makes consumers aware of new products, educates them about the features and benefits of the brand, and facilitates creating the image of a company that 
produces a product or service. Promotion is a top priority because sago local food products are introduced to local communities and outsiders to increase product sales. Consumers will choose products providing satisfaction to repeat purchases. If consumers are satisfied with a product, they will continue to buy it, use it, and inform others about its strength based on experience (Timisela, Leatemia, Luhukay, Polnaya, \& Breemer, 2020).

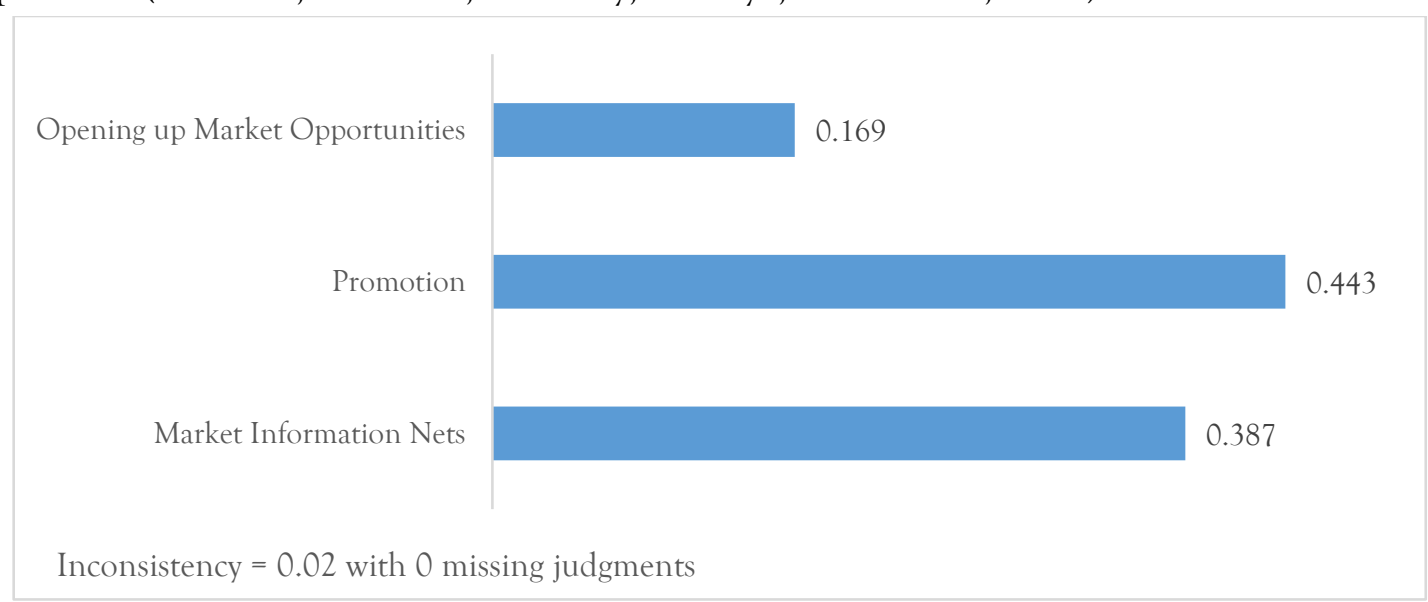

\section{FIGURE 7. MARKETING SUB-FACTORS FOR SAGO AGROINDUSTRY DEVELOPMENT}

The promotion aims to build consumers' perceptions that all family members can consume sago local food. Through mouth to mouth and direct marketing, local sago promotion is carried out in the market when transactions occur between buyers and sellers. Meanwhile, other promotional components have not been carried out optimally due to limited entrepreneurial capital and local governments' attention. Information networks are the second priority because they build cooperation between agroindustry entrepreneurs and other supply chain actors such as farmers, traders and consumers.

Sago local food agroindustry entrepreneurs need to seek information about changes and market opportunities for agroindustrial products. Opening market opportunities are the last priority because the sago agroindustry begins to utilize market opportunities using outlets, culinary and souvenir center markets, and supermarkets. Almost all culinary and souvenir centers in Ambon City sell processed sago products (Timisela, 2006).

\section{Role of Actors for Sago Agroindustry Development}

The actors playing an essential role in the sago agroindustry development include the Department of Industry and Commerce, the Department of Agriculture, the Department of Cooperatives and Small and Medium Micro Enterprises, the Food Security Agency, NonGovernmental Organizations (NGOs), universities, farmers, traders and entrepreneurs. The analysis of the role of actors for sago agroindustry development is presented in Figure 8. The analysis results uncover that the Department of Industry and Commerce is a top priority because its policies prioritize Maluku's local food development. The Department of Agriculture deals with mentoring and fostering farmers' sago forest management to increase the sago plant's productivity. The Department of Cooperatives and Small and Medium Micro Enterprises collaborates with agroindustrial entrepreneurs to support business capital and promote local food products. The Food Security Agency pays attention to the production, 
distribution, and consumption of sago local food to make people care and not forget sago as the local food of Maluku people.

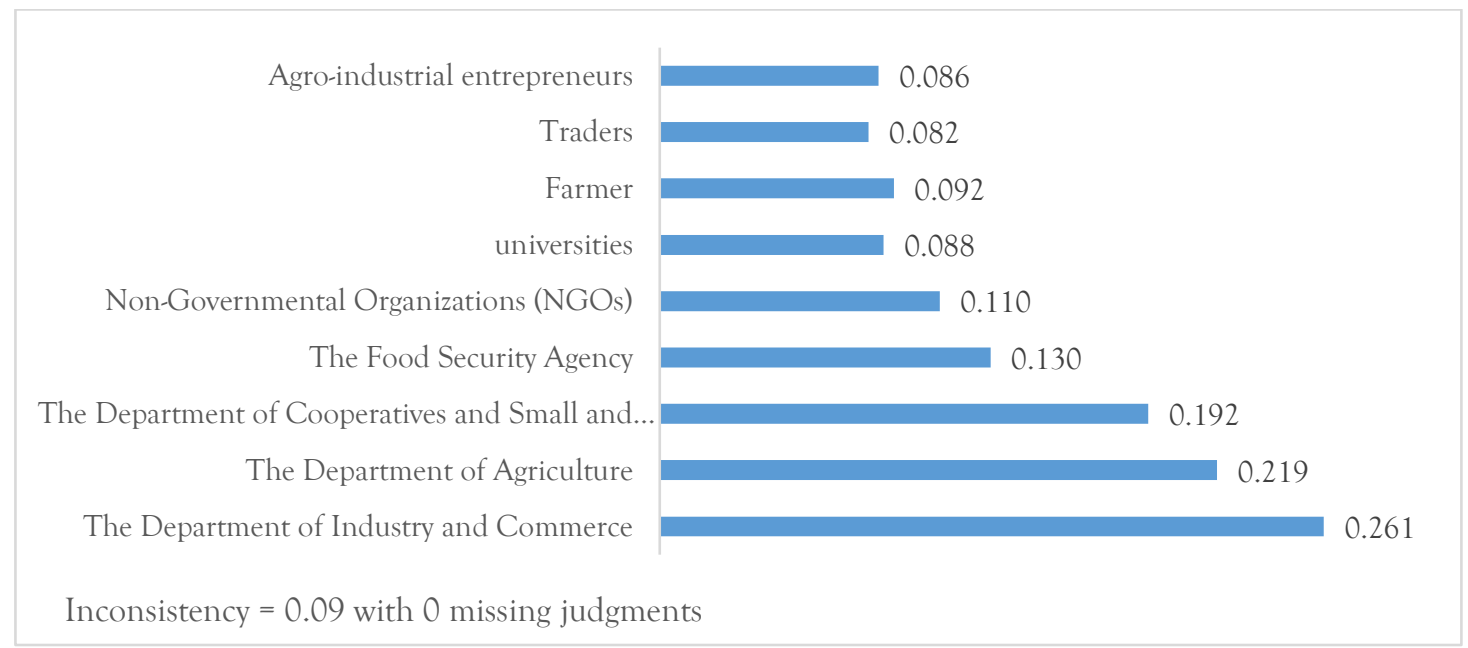

FIGURE 8. RESULTS OF PROCESSING THE ROLE OF ACTORS FOR SAGO AGROINDUSTRY DEVELOPMENT

The local government has carried out various policies to develop the sago local food agroindustry through the related institutions. Research of (Fakhrurrazi, Bantacut, \& Raharja, 2018) suggests that local government through related agencies is responsible for issuing various policies right on target and providing counseling and assistance to farmers and agrotourism businesses, while universities and research institutions are responsible for producing technology and science, as well as skilled human resources to carry out various kinds of innovations. Financial institutions also have an essential role because agrotourism based on the cocoa agroindustry cannot be carried out properly without capital support.

Higher education institutions and NGOs have a stake in preparing science, knowledge, and technology to develop local food agroindustries. Community service activities are carried out by the two institutions to empower the sago processing community. It is in line with the seaweed business development research, in which the supporting policy required is intensive assistance from related agencies, policies, regulations, and government intervention to attract as many investors as possible (Picaulima, Ngamel, Hamid, \& Teniwut, 2016).

Farmers, traders and entrepreneurs have the smallest weight. Farmers as raw material providers sometimes have not received adequate treatment, such as assistance to produce quality raw materials, limited capital, limited production facilities and infrastructure. Traditional traders still utilize not environmentally friendly packaging, limited product labeling, not maximized product sales, and limited sales places. Entrepreneurs have been unable to manage agroindustrial businesses continuously and adequately.

\section{Objectives of Sago Agroindustry Development}

The analysis results of sago agroindustry development objectives are depicted in Figure 9. Sago agroindustry development's objectives consist of five alternatives: expanding employment opportunities, increasing integrated supply chain management (MRP), improving marketing mechanisms, increasing businessmen's income, and increasing regional income. Expanding employment is a top priority because job creation can be sourced from 
the agroindustry sub-sector. Most agroindustries recruit workers in rural areas because it is easier to control work, help people having no job to earn income, and low-skilled workers can be facilitated because the local food agroindustry does not require special skills, thereby overcoming poverty and unemployment in rural areas.

Increasing integrated MRP is vital because it relates to farmers as suppliers of raw material suppliers, entrepreneurs as producers of products, traders as distributors of products, and consumers as end-users of products. The increase in market mechanisms is not optimal because it requires other parties' intervention for the smooth marketing of agroindustrial products.

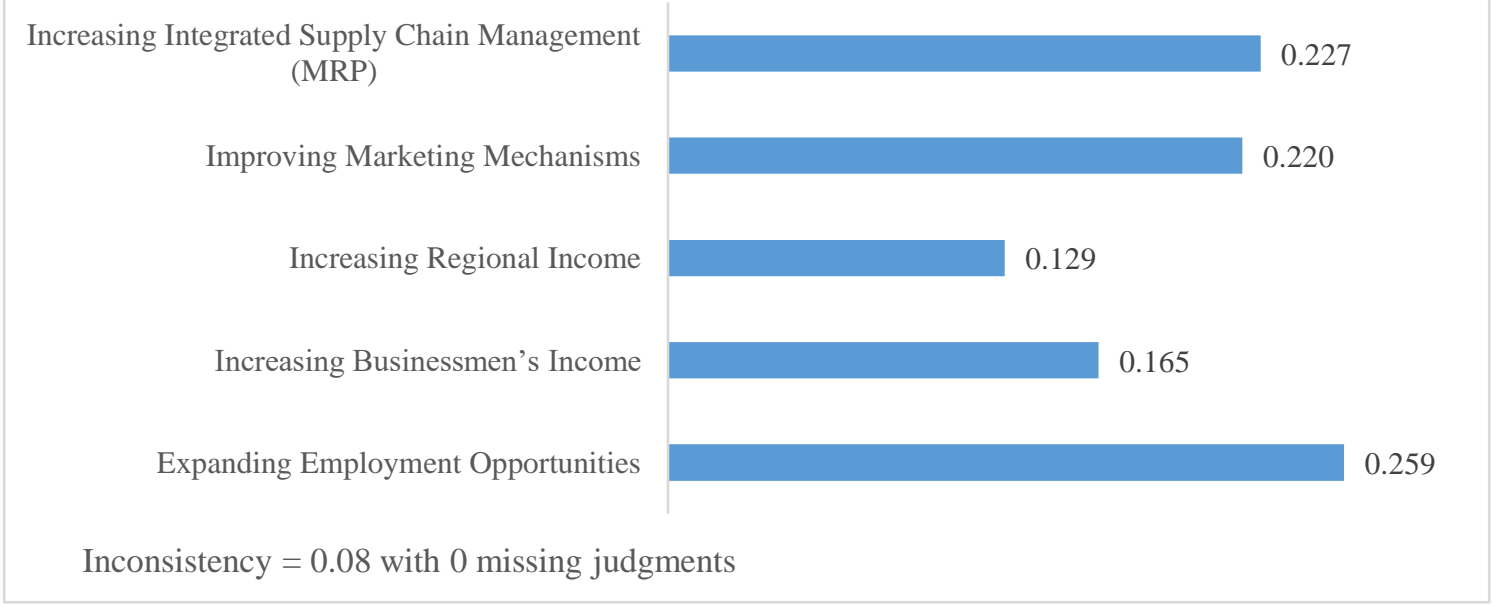

FIGURE 9. RESULT OF ANALYSIS OF SAGO AGROINDUSTRY DEVELOPMENT OBJECTIVES

\section{Policy Scenarios of Sago Agroindustry Development}

The sago agroindustry policy consists of five alternatives: improving infrastructure facilities, increasing output prices, improving technology, improving the institutional system, and preserving sago local food. Figure 10 demonstrates the policy analysis results of sago agroindustry development. Preservation of local food is a top priority and is regulated in the Regional Regulation (PERDA) of Maluku Province concerning Sago Management and Conservation No. 10 of 2011.

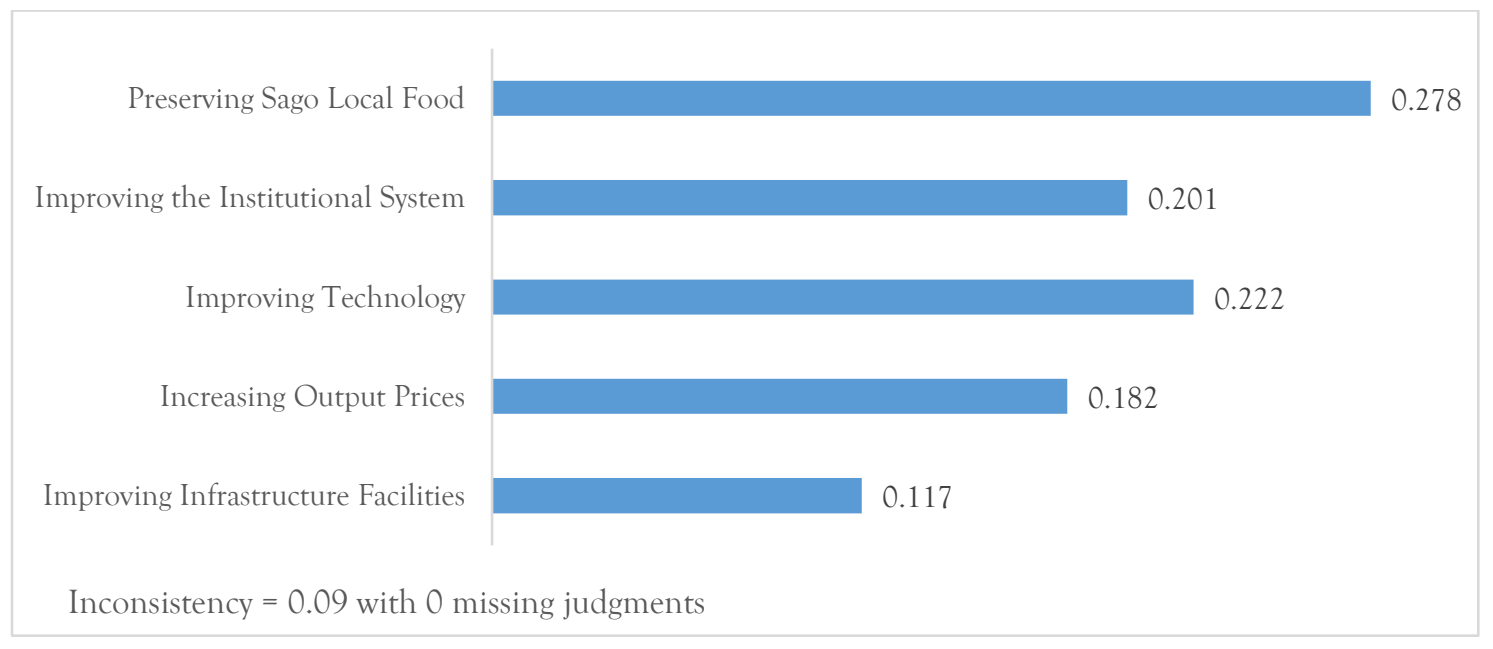

FIGURE 10. RESULT OF SCENARIO ANALISIS OF SAGO AGROINDUSTRY DEVELOPMENT POLICY 
The second priority is the improvement of processing technology. It is essential due to the introduction of new technologies for agroindustry development. There needs to be a change in the raw material production process from a manual to a mechanical system. Improvement of institutional systems covers financial institutions, business group institutions, farmer group institutions, and supply chain partnership institutions. Attention to agroindustry with an institutional design considers all components of the system adapted to a change in the paradigm of decentralized development, prioritizes community initiatives, and impacts social, economic, cultural, and environmental lives.

Attention to an increase in output prices aims to ensure that prices are set according to product quality and costs incurred in the production process. Facilities and infrastructure receive the last priority, whereas the progress and decline of agroindustry depend on facilities and infrastructure such as business equipment, production machinery, roads, bridges, transportation, ports and others.

\section{Sago Local Food Agroindustry Development Strategy}

Economic development focuses on shifting from the agricultural to the industrial sector. The transformation of the agricultural sector is essential because of the perishable nature of agricultural products, and it does not last long without special handling, takes up space, is seasonal, varies in quality, and located in rural areas. As the best solution to accommodate agricultural products, agroindustry is further processed into valuable and competitive products. Agroindustry is a means of increasing added value, creating jobs, expanding markets for agricultural production, supporting income and increasing farmers' welfare (Basalamah, 2004).

The sago agroindustry in rural Maluku is an opportunity to create jobs, increase added value, community, and village income, as well as improve the people's economy. Resources based industry as the agroindustry character, development direction, and strategy is based on a regional approach as an area having potential resources with a footing on the comparative advantage concept (Syam \& Ma'arif, 2004). There is a need for a touch of the regional agricultural development policy to improve farmers' welfare (Witjaksono, Sulle, \& Subaedah, 2008). The agroindustry sector serves as a basis for increasing product added value, absorbing excess labor and increasing household income (Susilowati, Sinaga, Limbong, \& Erwidodo, 2007; Indrawanto, 2008).

The analysis results using the AHP technique based on combining the opinions of experts and the principle of pairwise comparisons reveal the priority values, as presented in Table 1.

TABLE 1. PRIORITY ALTERNATIVE STRATEGIES FOR SAGO LOCAL FOOD AGROINDUSTRY DEVELOPMENT

\begin{tabular}{lll}
\hline \multicolumn{1}{c}{ Focus } & \multicolumn{1}{c}{ Priority Alternative } & Value \\
\hline Main Factors & Technology & 0.314 \\
Sub-Factors & Capital assistance & 0.750 \\
Actors & Department of Industry and Commerce & 0.261 \\
Objectives & Expansion of employment & 0.259 \\
Policy Scenarios & Preservation of local food & 0.278 \\
\hline
\end{tabular}




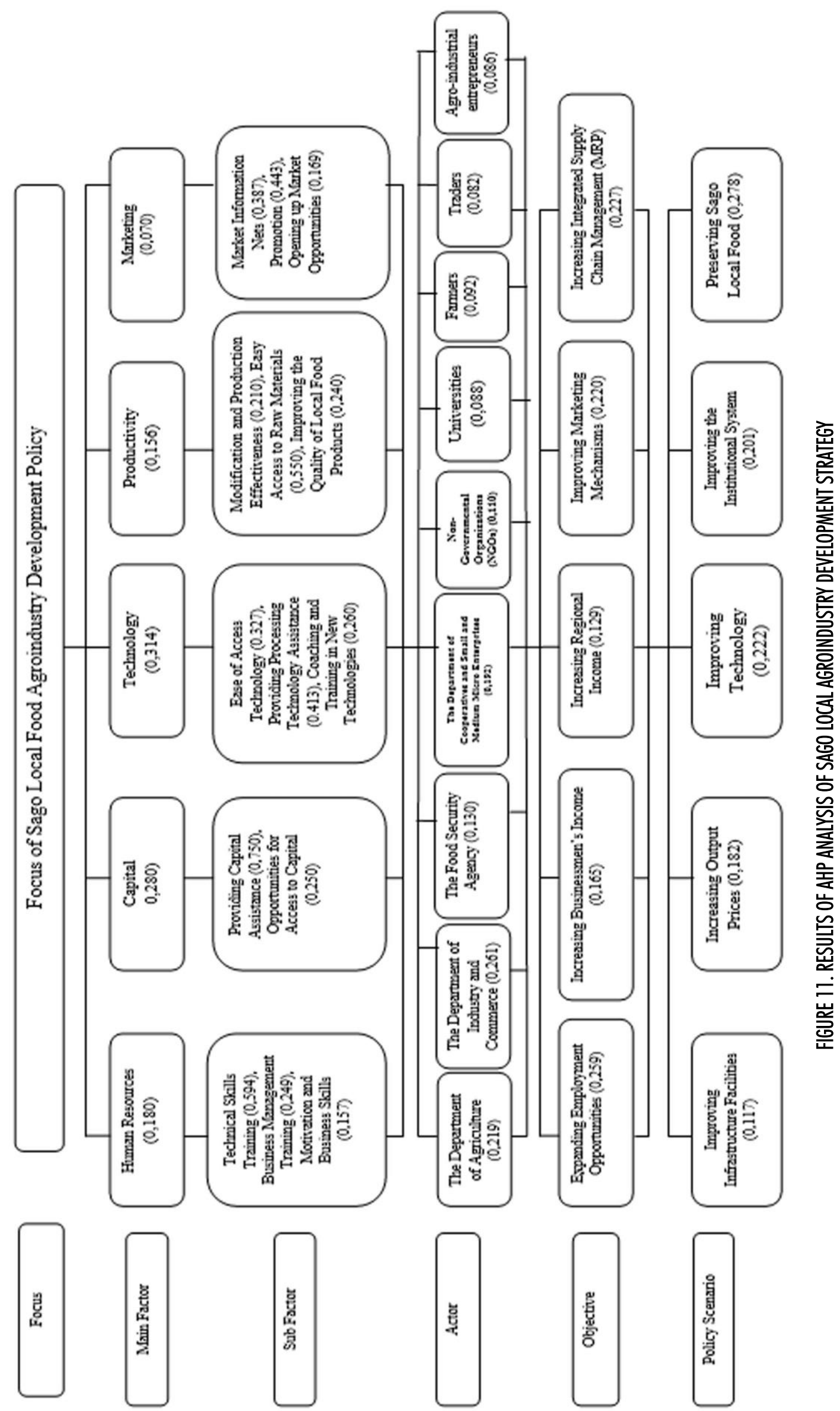


Overall, AHP analysis results on aspects and alternatives of sago agroindustry development with an inconsistency ratio of 0.05 are less than 0.1 ; thus, the analysis is accepted that shown at Figure 11. The main factor becoming a priority is technology. It is essential for the agroindustry since it improves product quality, business equipment, and product packaging and labeling.

The sub-factors for the sago local food agroindustry development have been analyzed quite a lot, but the priority was capital assistance. So far, entrepreneurs have only relied on their capital to move their business. Therefore, capital assistance from financial institutions such as banks, savings and loan cooperatives, and credit unions is essential to help them develop their business. Research of Raharja, Rivani, \& Afifianti (2018) unveils that it is necessary to improve production techniques and designs and easy access to business capital financing to compete in sustainably increasing export market penetration. It is the same as Sudantoko (2010) regarding developing small-scale businesses to become development priorities by opening market opportunities and training to expand entrepreneurial potential and provide trading and marketing houses.

Actors are the priority of the Department of Industry and Commerce. Sago local food agroindustry entrepreneurs require training, assistance, and guidance from the Department of Industry and Commerce because it is an important institution that will help entrepreneurs develop their agroindustry. The Department of Industry and Commerce is usually the provider of equipment technology assistance and training to improve human resources quality for processing sago local food.

The priority objective is employment expansion. When the agroindustry business develops well, it will become an employment source for other people in rural areas. The sago local food agroindustry is located in rural areas because it is closer to raw materials. When the business develops well, other people will be motivated to collaborate and even open job opportunities for others so that they can jointly develop the sago agroindustry in the countryside.

The priority policy scenario is the preservation of local food. When entrepreneurs continuously introduce sago agroindustry, many people will return to sago and prioritize it as the main local food. Nowadays, sago seems to be neglected because people only eat it as a snack, not the main staple food. It is necessary to continuously educate all people about sago local food to better understand the importance of consuming local food. In particular, it is necessary to become a local content in schools to be more familiar with sago local food and consume it as a prestigious food. Related agencies need to prioritize it for essential events at the department to continue to introduce sago to the general public. Sago local food must be preserved from generation to generation and sustainably for the next generation to make it the primadonna in Maluku.

Preservation of sago local food is essential because most industries such as food, adhesives, cosmetics, textiles, animal feed, pharmaceuticals, chemicals, pesticides, energy materials and by-products are processed into fuel, mushroom medium, hardboard or building materials, the primary source of which is sago raw materials (Kindangen \& Malia, 2003), and 
edible/biodegradable film (Polnaya, Talahatu, Haryadi, \& Marseno, 2012; Polnaya, Ega, \& Wattimena, 2016) (Polnaya, Alfons, \& Souripet, 2019).

\section{CONCLUSIONS}

Priority analysis of sago agroindustry development strategy reveals that technology is its top priority because it is related to assistance and access to processing technology, which is very low and limited. The second priority is capital because capital assistance and entrepreneur access to business capital are minimal, thereby affecting business continuity.

The focus of sago agroindustry development requires linkages between factors, subfactors, actors, objectives and policy scenarios. The expected policy scenarios include preserving sago food, improving technology, managing marketing strategies, improving production facilities and infrastructure, improving infrastructure and institutional systems. Supply chain actors and the government must have a joint commitment and be serious in advancing the sago agroindustry from upstream to downstream. Thus, supply chain actors will ultimately be more independent in ideal agroindustrial management.

\section{REFERENCES}

Andriani, F. Y., Astari, D. I., Budhiarti, D., \& Zachary, K. M. (2017). Analisis pengambilan keputusan strategi pengembangan industri kreatif kulit ikan pari Yogyakarta dengan pendekatan SWOT dan AHP. In Human-centered Creative Industries, Industrial Engineering National Conference (pp. 288-295).

Apulu, I., \& Latham, A. (2011). Drivers for Information and Communication Technology Adoption: A Case Study of Nigerian Small and Medium Sized Enterprises. International Journal of Business and Management, 6(5), 51-50. doi:10.5539/ijbm.v6n5p51

Ariani, M., Hermanto, Hardono, S. H., Sugiarto, \& Wahyudi, T. S. (2013). Kajian Strategi Pengembangan Diversifikasi Pangan Lokal. Bogor. Retrieved from http://pse.litbang.pertanian.go.id/ind/pdffiles/anjak_2013_06.pdf

Basalamah, S. (2004). Optimasi aktivitas agroindustri Markisa di Kabupaten Gowa. Jurnal Analisis, 1(2), 88-96.

Chalids, I., Najib, M., \& Suparno, O. (2019). Strategi pengembangan usaha tani tomat dalam upaya menembus Singapura (Studi kasus mitra Tani Parahyangan). Jurnal Aplikasi Bisnis Dan Manajemen, 5(1), 24-33. doi:10.17358/jabm.5.1.24

Chen, C.-C., Yueh, H.-P., \& Liang, C. (2016). Strategic Management of Agribusiness: Determinants and Trends. Agricultural Management, Marketing and Finance Occasional Paper, 12(4), 69-98.

Didu, M. S. (2000). Rancangbangun Strategi Pengembangan Agroindustri Kelapa Sawit (Agrosawit). Jurnal Teknik Industri Pertanian, 11(1), 20-26.

Fadhil, R., Maarif, M. S., Bantacut, T., \& Hermawan, A. (2018). A prospective strategy for institutional development of gayo coffee agroindustry in aceh province, Indonesia. Bulgarian Journal of Agricultural Science, 24(6), 959-966. 
Fadhil, R., Syamsul, M. M., Bantacut, T., \& Hermawan, A. (2017). A Review on the Development Strategies of Agro-industrial Institutions in Indonesia. Asian Journal of Applied Sciences, 5(4), 747-763. Retrieved from www.ajouronline.com

Fakhrurrazi, Bantacut, T., \& Raharja, S. (2018). Model Kelembagaan Pengembangan Agrowisata Berbasis Agroindustri Kakao di Kabupaten Pidie Jaya Provinsi Aceh. Jurnal Manajemen Teknologi, 17(3), 244-260. doi:10.12695/jmt.2018.17.3.6

Fatah, L. (2007). The potentials of agro-industry for growth promotion and equality improvement in Indonesia. Asian Journal of Agriculture and Development, 4(1), 57-74

Gultom, J. Y. T., \& Sulistyowati, L. (2018). Strategi Pengembangan Agroindustri Manisan Mangga (Studi Kasus pada UMKM Satria di Kecamatan Kedawung, Kabupaten Cirebon). Jurnal Ilmiah Mahasiswa AGROINFO Galuh, 5(1), 961-972

Herdhiansyah, D., \& Asriani. (2018). Strategi pengembangan agroindustri komoditas kakao di Kabupaten Kolaka - Sulawesi Tenggara. Jurnal Agroindustri Halal, 4(1), 30-41

Indrawanto, C. (2008). Penentuan pola pengembangan agroindustri jambu mete. Jurnal Penelitian Tanaman Industri, 14(2), 78-86. doi:10.21082/jlittri.v14n2.2008.78-86

Kindangen, J. G., \& Malia, I. E. (2003). Pengembangan potensi dan pemberdayaan petani sagu di Sulawasi Utara. In Sagu untuk Ketahanan Pangan. Bogor: Pusat Penelitian dan Pengembangan Perkebunan

Kumar, M., Agarwal, A., Singh, P., \& Singhal, A. K. (2017). Green packaging and marketing in promoting agribusiness. Green Packaging and Marketing in Promoting Agribusiness, 3(1), $17-24$

Kurnia, D., \& Al-Irsyadsyah, M. (2017). Strategi Pengembangan Agroindustri Sagu Kab. Indragiri Hilir Riau. Jurnal BAPPEDA, 3(3), 151-161

Kusnandar, Rahayu, W., Setyowati, N., \& Sutrisno, J. (2016). Strategy planning formulation for agroindustry based on cassava to anticipate climate change (SWOT analysis and balance scorecard approach). In International Conference on Climate Change (pp. 3-14). doi: $10.15608 /$ iccc.y2016.545

Massinai, R., Sudira, P., Mawardi, M., \& Darwanto, D. H. (2013). Strategi pengembangan agroindustri berbasis sistem usahatani terpadu di wilayah pasang surut (Studi kasus: Kabupaten Pulang Pisau Provinsi Kalimantan Tengah). Agritech, 33(2), 234-243

Nurhayati, I., Sumarno, S., \& Indrawati, H. (2016). Strategi Pengembangan Usaha Tepung Sagu Di Kecamatan Tebing Tinggi Barat Kabupaten Kepulauan Meranti. Jurnal Online Mahasiswa, 3(2), 1-12

Picaulima, S. M., Ngamel, A. K., Hamid, S. K., \& Teniwut, R. M. K. (2016). Analisis kelayakan usaha agroindustri rumput laut di Kabupaten Maluku Tenggara. Jurnal Sosial Ekonomi Kelautan Dan Perikanan, 10(1), 91-102. doi:10.15578/jsekp.v10i1.1250

Polnaya, F. J., Alfons, N. D. J., \& Souripet, A. (2019). Karakteristik edible film komposit pati sagu molat-pektin. Buletin Palma, 20(2), 111. doi:10.21082/bp.v20n2.2019.111-118

Polnaya, F. J., Ega, L., \& Wattimena, D. (2016). Karakteristik edible film pati sagu alami dan pati sagu fosfat dengan penambahan gliserol. Jurnal Agritech, 36(03), 247. doi:10.22146/agritech.16661 
Polnaya, F. J., Talahatu, J., Haryadi, \& Marseno, D. W. (2012). Properties of biodegradable films from hydroxypropyl sago starches. Asian Journal of Food and Agro-Industry, 5(03), 183-192.

Putri, D. L., Annisa, M., Ningrum, L. P., Mursid, M., Amiadji, \& Murdjito. (2015). Agro Industrial Cluster Development Strategy Coastal Region District Banyuwangi. Procedia Earth and Planetary Science, 14, 136-143. doi:10.1016/j.proeps.2015.07.094

Raharja, S. J., Rivani, \& Afifianti, R. (2018). Strategy of development of ceramic industry with analytic hierarchy process: Study on ceramic industry center in Purwakarta, Indonesia. AdBispreneur Jurnal Pemikiran dan Penelitian Administrasi Bisnis dan Kewirausahaan, 3(3), 229-240. doi:10. 19540 /j. cnki. cjcmm. 20190128. 002

Rosmawaty, Wunawarsih, I. A., Bahari, \& Yusria, W. O. (2017). Potential and development strategy of cocoa agroindustry in Southeast Sulawesi. IOSR Journal of Business and Management, 19(9), 1-6. doi:10.9790/5933-08040XXXX

Saaty, T. L. (2008). Decision making with the analytic hierarchy process. International Journal of Services Sciences, 1(1), 83-98.

Sudantoko, J. (2010). Pengembangan industri batik skala kecil di kabupaten dan kota pekalongan dengan pendekatan analysis hierarchy process (AHP). Prestasi, 6(1), 1-17.

Suryana, A. (2005). Arah, Strategi dan Program Pembangunan Pertanian 2005-2009. Jakarta.

Susilowati, S. H., Sinaga, B. M., Limbong, W. H., \& Erwidodo, N. F. N. (2007). Dampak kebijakan ekonomi di sektor agroindustri terhadap kemiskinan dan distribusi pendapatan rumah tangga di Indonesia: Analisis simulasi dengan sistem neraca sosial ekonomi. Jurnal Agro Ekonomi, 25(1), 11-36. doi:10.21082/jae.v25n1.2007.11-36

Syam, H., \& Ma'arif, M. S. (2004). Kajian perlunya kebijakan pengembangan agroindustri sebagai leading sector. Agrimedia, 9(1), 32-39.

Tahitu, M. E., Saleh, A., Lubis, D. P., \& Susanto, D. (2016). Strategi Pengembangan Kapasitas Pengelola Sagu di Maluku Tengah Provinsi Maluku. Sosiohumaniora, 18(1), 39-46. doi:10.24198/sosiohumaniora.v18i1.9355

Tarigan, D., Fauzi, A. M., Sukardi, Suryani, A., \& Kaomini, M. (2010). Strategi pengembangan agroindustri sutera alam melalui pendekatan klaster. Jurnal Teknologi Industri Pertanian, 20(1), 39-47.

Timisela, N. R. (2006). Analisis usaha rumahtangga sagu dan pemasarannya. Jurnal Agroforestri, 1(3), 57-64. Retrieved from https://www.researchgate.net/publication/298698070

Timisela, N. R., Leatemia, E. D., Luhukay, J. M., Polnaya, F. J., \& Breemer, R. (2020). An analysis of factors influencing consumers' perception towards the product attributes of sago local food agro-industry. International Journal of Innovation, Creativity and Change, 12(6), 500-518.

Timisela, N. R., Masyhuri, Darwanto, D. H., \& Hartono, S. (2014). Manajemen rantai pasok dan kinerja agroindustri pangan lokal sagu di Propinsi Maluku: Suatu pendekatan model persamaan struktural. Agritech, 34(2), 184-193. doi:10.22146/agritech.9509 
Udayana, I. G. B. (2011). Peran Agroindustri dalam Pembangunan Pertanian. Jurnal Teknologi Industri Pertanian, 44, 3-8.

Wijaya, O. (2017). Strategi Pengembangan Komoditas Pangan Unggulan dalam Menunjang Ketahanan Pangan Wilayah (Studi Kasus di Kabupaten Batang, Propinsi Jawa Tengah). AGRARIS: Journal of Agribusiness and Rural Development Research, 3(1), 48-56. doi:10.18196/agr.3144

Witjaksono, J., Sulle, A., \& Subaedah, R. (2008). Strategi akselerasi peningkatan pendapatan petani jambu mete di Sulawesi Tenggara. SOCA Jurnal Sosial Ekonomi Pertanian, 8(1), 1 18.

Yamin, M., Ali, M. S. S., MI, R., Fahmid, I. M., \& Asri, S. (2018). Agroindustry Development Policy: A Strategy towards Poverty Alleviation. Journal of Sustainable Development, 11(3), 258-269. doi:10.5539/jsd.v11n3p258 